DOI 10.31558/2307-2318.2019.1.1

УДК 331.2

Ведерніков М.Д., д.е.н., професор кафедри управління персоналом і економіки праці Хмельницького національного університету

Баксалова О.М., к.е.н., доцент кафедри економіки, менеджменту та адміністрування Хмельницького національного університету

\title{
НАУКОВО-ТЕОРЕТИЧНІ І МЕТОДИЧНІ ПІДХОДИ ВИМІРУ ЗДІБНОСТЕЙ РОБІТНИКІВ ДО ПРАЦІ НА ПРИКЛАДІ ПОТОКОВО-КОНВЕСРНОГО ВИРОБНИЦТВА
}

Розглянуто науково-теоретичні і методичні підходи виміру здібностей робітників до праці на основі інтеграції різноманітних способів встановлення індивідуальних і необхідних витрат праці та сучасних аналітичних методів нормування праці шляхом їх доповнення та взаємозбагачення. 3'ясовано поняття особистого нормативного трудового навантаження як основи визначення ціни купівлі-продажу робочої сили між найманим робітником та власником-роботодавцем. Запропоновано послідовнопоетапний метод проведення дослідження на прикладі потоково-конвеєрного виробництва.

Ключові слова: праця, ринок праці, потоково-конвеєрне виробництво, індивідуальні витрати праці, нормативно трудове навантаження.

Ведерников М.Д., Баксалова О.М.

\section{НАУЧНО-ТЕОРЕТИЧЕСКИЕ И МЕТОДИЧЕСКИЕ ПОДХОДЫ ИЗМЕРЕНИЯ СПОСОБНОСТЕЙ РАБОТНИКОВ К ТРУДУ НА ПРИМЕРЕ ПОТОЧНО-КОНВЕЕРНОГО ПРОИЗВОДСТВА}

Рассмотрены научно-теоретические и методические подходы измерения способностей рабочих к труду на основи интеграции различных способов установления индивидуальных и необходимых затрат труда и современных аналитических методов нормирования труда путем их дополнения и взаимообогащения. Выяснено понятие индивидуальной нормативной трудовой нагрузки как основы определения цены куплипродажи рабочей силы между наемным рабочим и собственником-работодателем. Предложено последовательно-поэтапный метод проведения исследования на примере поточно-конвейерного производства.

Ключевые слова: труд, рынок труда, поточно-конвейерное производство, индивидуальные затраты труда, нормативно трудовая нагрузка.

Vedernikov M., Baksalova O.

SCIENTIFIC-THEORETICAL AND METHODOLOGICAL APPROACHES TO MEASUREMENT OF THE WORKERS 'ABILITIES FOR WORK ON THE EXAMPLE OF THE FLOW-CONVERGING MANUFACTURE

The scientific-theoretical and methodological approaches to measuring the abilities of workers to work are considered on the basis of integration of various ways of establishing individual and necessary labor costs and modern analytical methods of labor valuation by their addition and mutual enrichment. The notion of personal normative labor load as the basis for determining the price of labor-power sales between the hired worker and the employer-owner is determined. A sequential-stage method of conducting research on the example of flowconveyor production is offered.

Key words: labor, labor market, flow-conveyor production, individual labor costs, normative labor load. 
Постановка проблеми. Організаційно-економічний механізм регулювання оплати праці робітників в умовах ринкової моделі економіки на рівні підприємства, фірми, компанії грунтується на законі вартості, згідно з яким робоча сила, подібно будьякому іншому товару, продається і купується за певну ціну, в основі якої лежить вартість цього специфічного товару. Практично відбувається це у вигляді обміну певної кількості та якості праці, що являють собою втілені в певні результати роботи (продукцію, послуги тощо) здібності робітників до праці, на визначений розмір заробітної плати. Ці обставини потребують вирішення проблеми виміру здібностей робітників до праці та встановленні кожному з них (при виконанні певної операції, роботи чи комплексу робіт) визначеного обсягу особистого нормативного трудового навантаження, який він може виконати відповідно до своїх здібностей до праці за певний час у даних організаційнотехнічних умовах виробництва та обміняти на відповідний розмір заробітної плати.

Аналіз останніх досліджень і публікацій. Дослідження останніх публікацій у відкритому друці як у вітчизняній, так і зарубіжній літературі свідчить про відсутність будь-яких рекомендації й методичних підходів щодо виміру здібностей робітників до праці. Це пояснюється складністю проблеми i невизначеністю основних фундаментальних положень і понять, які лежать в основі цієї проблеми. Так, існують суттєві розбіжності при розумінні самого поняття "здібності", тривають дискусії про роль і значення фізичного і соціального в змісті здібностей, залишається невирішеною проблема діагностики здібностей, існують певні непорозуміння щодо напрямку пошуку ефективних концепцій встановлення здібностей до конкретних видів трудової діяльності тощо. Аналіз наукових праць зарубіжних i вітчизняних вчених, що проводять дослідження у сфері праці свідчить, що вони досліджують комплекс проблем пов'язаних, головним чином, з визначенням нормативних і фактичних витрат праці. При цьому розглядається досить широке коло різноманітних питань, а саме: аналіз, планування, організація, контроль та управління нормуванням праці в умовах ринкової економіки. У цьому аспекті напрацьовано досить великий теоретичний, методичний i практичний матеріал.

Формулювання цілі статті. Метою статті $\epsilon$ вироблення науково-теоретичних підходів і методичних рекомендацій виміру здібностей робітників до праці, що $\epsilon$ основою організації оплати праці робітників в умовах ринкової моделі економіки та запорукою найбільш повного й ефективного використання ресурсу їх робочої сили.

Виклад основного матеріалу дослідження. Ринкова ціна робочої сили, що визначається на основі попиту і пропозиції на ринку праці, не може бути безпосередньо ціною купівлі-продажу робочої сили конкретного робітника оскільки, вона не враховує професійні, ділові та особисті дані робітника, його вміння, знання, досвід, його творчість, креативність, фізичні дані тощо, все те, що зумовлює результати його роботи і визначає дійсну цінність робочої сили будь-якого робітника. У своєму бестселері "Політична економія: дискусійні проблеми, шляхи оновлення" С.В. Брагінський та Я.А. Певзнер відзначають, що, якщо "прийняти тезу, згідно з якою наймач купує робочу силу, здібність до праці, то необхідно виходити з того, що оцінює він цю здібність не за тим, скільки і чого потрібно робітникові для підтримання його життя і працездатності, а насамперед за результатами праці, тобто за тим, яка плідність праці кожного власника робочої сили зокрема" [3, с. 185].

Разом із тим, дослідження проблеми виміру здібностей робітників до праці показує, що вона носить інтегральний характер і вимагає врахування багатьох організаційних, технічних, економічних, виробничих та інших факторів, які прямо або побічно впливають на трудовий процес робітника та визначають результати його праці. 
Тому пропонується послідовний метод розв'язання цієї проблеми з виділенням окремих етапів. Розглянемо це на прикладі потоково-конвеєрного виробництва з виробленням певних теоретичних підходів і практичних рекомендацій. Отже, пропонується такий алгоритм.

Перший етап - попереднє дослідження операції за матеріалами технічної, технологічної, економічної та іншої документації, в процесі якого з'ясовується мета та призначення операції, технологічна послідовність ії виконання, вимоги щодо якості продукції, техніки безпеки, культури виробництва та виробничої санітарії. Ретельно вивчаються техніко-експлуатаційні дані устаткування, конструкція виробу та технологічне оснащення робочого місця. При цьому вивчається можливість зняття 3 виробництва застарілої продукції й обладнання та перспектива появи нових виробів та технологічних процесів. Встановлюються вимоги, що пред'являються до сировини, матеріалів, напівфабрикатів. Визначаються об'єктивні дані, що характеризують виконавця операції, а саме: вік, освіта, стаж роботи, виробничий досвід, кваліфікація, рівень виконання норм праці тощо. 3'ясовуються способи встановлення норм праці, методи нормування праці, форми та системи оплати праці, порядок преміювання та стимулювання праці робітників.

При необхідності з урахуванням специфіки виробництва може досліджуватись інша інформація, що потребується для точного виміру здібностей робітників до праці та встановлення кожному з них особистого нормативного трудового навантаження.

Джерелом інформації слугує конструкторська та технологічна документація, ДСТУ, паспорта на устаткування, різноманітні аналітичні, нормативні, економічні та інструктивні матеріали, дані оперативного та статистичного обліку тощо.

Другий етап - дослідження організації праці та виробництва безпосередньо на робочому місці у реальних виробничих умовах. Змістом даного етапу є вивчення існуючих організаційно-технічних умов виробництва продукції, в процесі якого визначаються фактичні режими роботи машин, устаткування, приладів і т. ін.; встановлюється дотримання вимог щодо технологічного процесу, режимів праці та відпочинку, якості праці та продукції, охорони праці та виробничої санітарії; визначається порядок і система обслуговування робочих місць, оцінюється стан 3 організації, нормування та оплати праці робітників тощо.

За результатами дослідження робиться порівняльний аналіз реальних виробничих умов виконання операції, роботи чи комплексу робіт із запроектованими у відповідних нормативних документах. У випадку виявлення розбіжностей встановлюються причини, що їх спричинили, а при необхідності приймаються заходи щодо їх усунення.

Важливим напрямком роботи на даному етапі $\epsilon$ також ознайомлення 3 робітником, що безпосередньо виконує операцію. Контакт з ним необхідний 3 двох причин. По-перше, невідомість мети дослідження, що проводиться, буде нервувати робітника, він може притишити свій темп роботи або, навпаки, підвищити його, може змінити структуру елементів та послідовність їх виконання і т. ін., тобто невимушено лишити спостерігача можливості отримати якісні матеріали. По-друге, робітник може сприйняти відсутність інформації щодо роботи, яка проводиться на його робочому місці як неповагу до себе та навмисно лишити дослідника можливості отримати якісні, достовірні матеріали.

Встановлення контакту з робітником припускає не тільки повну інформацію щодо мети дослідження, але й залучення його до дослідження, що проводиться. Практика свідчить, що найбільш якісні матеріали, а на їх основі й рекомендації можна отримати 
лише в результаті творчої професійної співдружності робітників та спостерігачівдослідників.

Третій етап - аналіз трудового процесу виконання операції, в процесі якого встановлюється структура рухів в їх взаємозв'язку та взаємозалежності й послідовність їх виконання. Встановлюються необхідні, ключові, контрольні, допоміжні та інші рухи 3 оцінкою необхідності та доцільності виконання кожного з них. При цьому визначається відстань переміщення рухів та переходів робітника, ступінь тактильного та зорового контролю виконання рухів, наявність зайвих, нераціональних, помилкових та “аварійних" рухів, суміщення рухів у часі та просторі тощо. Водночас виявляються недоліки в організації праці й виробництва та обслуговуванні робочих місць, що зумовлюють прямі втрати та нераціональні витрати робочого часу.

На основі дослідження встановлюється найбільш раціональна структура рухів та проектується найбільш оптимальний метод виконання операції.

Четвертий етап - визначення нормативних, тобто абсолютно необхідних витрат праці, які потрібні для виконання певної операції в даних суспільно нормальних умовах виробництва та при середньому у даному суспільстві рівні вмілості та інтенсивності праці. Ця робота проводиться за допомогою існуючих способів встановлення норм праці та методів нормування праці (які обираються в кожному конкретному випадку залежно від специфіки техніки, технології, організації праці й виробництва) з дотриманням усіх вимог, що пред'являються до проведення нормувальних робіт.

П'ятий етап - проведення спостереження та визначення фактичних витрат праці конкретного робітника, які він реально витрачає (згідно зі своїми здібностями до праці) на виконання цієї ж самої операції та в тих самих організаційно-технічних умовах виробництва. Технічні засоби та способи їх визначення й обробки також обираються в кожному конкретному випадку залежно від особливостей операції та умов виробництва.

Шостий етап - встановлення індивідуального індексу здібностей робітника до праці, який пропонується визначати як добуток від ділення нормативних витрат праці, що вимагаються робітнику середніх здібностей до праці для виконання операції, роботи або комплексу робіт в даних організаційно-технічних умовах виробництва до витрат праці, що фактично витрачає конкретний робітник на виконання цієї ж самої операції, роботи або комплексу робіт в тих самих умовах виробництва. При цьому до розрахунку індексу включаються лише ті витрати праці, що пов'язані 3 трудовою діяльністю робітника, коли він безпосередньо діє на предмет праці та робить 3 ним відповідні кількісні і (або) якісні зміни, а отже й проявляє свої здібності до праці.

У зв'язку з цим, до складу необхідних, а отже, відповідно, і витрат праці робітника не включаються перерви на відпочинок та особисті потреби, перерви, що встановлені технологією та організацією виробничого процесу, витрати часу на виконання підготовчо-заключної роботи та на обслуговування робочого місця.

Під час вищевказаних перерв робітник не працює та не здійснює свій трудовий процес. Він відпочиває, займається особистою гігієною, відправляє свої природні потреби, не працює з причини специфічних умов протікання технологічного процесу, а отже і не проявляє своїх особистих здібностей до праці.

Під час обслуговування робочого місця та у підготовчо-заключний час робітник безпосередньо не виконує виробничого завдання, а отже і не проявляє своїх здібностей до виконання дорученої йому операції. Він здійснює різноманітну роботу, пов'язану із підтриманням робочого місця у належному стані, виконує все необхідне для виконання виробничого завдання, а також робить різні дії, пов'язані із закінченням роботи. В умовах потоково-конвеєрного виробництва ця робота, як правило, виконується 
централізовано допоміжними робітниками (налагоджувальниками технологічного обладнання, слюсарями-ремонтниками, електриками, прибиральниками, вантажниками, комплектувальниками, розподілювачами робіт, змащувальниками устаткування, заточувальниками інструменту тощо), для яких вона $є$ вже основною роботою.

Таким чином, 3 вищенаведеного закономірно випливає висновок, що для визначення індивідуального індексу здібностей робітника до праці лишається тільки робота, що робітник виконує в циклі операції за такт потоку. У зв'язку з цим, пропонується така формула його визначення:

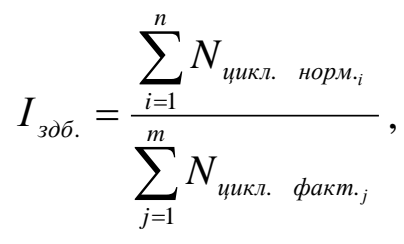

де $I_{\text {здб. }}$ - індивідуальний індекс здібностей робітника до праці;

$N_{\text {цикл. норм.і }}-$ нормативні витрати часу, що абсолютно необхідні $i$-му робітнику середніх здібностей до праці на виконання певної роботи в циклі операції за такт потоку, нормо-секунд (нормо-хвилин, нормо-годин і т. ін.);

$N_{\text {цикл. факт.j }}-$ фактичні витрати часу ј-го конкретного робітника на виконання цієї ж самої роботи в циклі операції за такт потоку, секунд (хвилин, годин і т. ін.).

Таким чином, за своєю сутністю індивідуальний індекс здібностей робітника до праці - це показник, що характеризує співвідношення необхідних витрат праці, які потребуються робітнику середніх здібностей до праці для виконання певної роботи або комплексу робіт в циклі операції у даних умовах виробництва, з витратами праці, які витрачаються конкретним робітником (згідно з його здібностями до праці) також в циклі операції при виконанні цієї ж самої роботи або комплексу робіт в тих самих умовах виробництва.

Абсолютна величина цього показника знаходиться у прямій залежності. Чим більшим є обсяг особистого нормативного трудового навантаження, що виконує робітник, і чим менше витрачає він часу на його виконання, тим більше одиниць необхідних витрат праці припадає на кожну одиницю фактичних витрат праці робітника, тим більш вищим є індекс його здібностей до праці, а отже і його здібності до виконання дорученої йому до виконання певної операції, роботи чи комплексу робіт та навпаки.

Сьомий етап - визначення здібностей робітника до праці в такті потоку за наступною формулою:

$$
K_{\text {здб.роб. }}=I_{\text {здб. }} \cdot t,
$$

де $K_{\text {здб.роб. }}-$ кількісна оцінка здібностей робітника до праці в такті потоку, нормосек. (нормо-хвилин, нормо-годин тощо).

3 метою визначення об'єму додаткового нормативного навантаження, що може бути встановлений робітникові понад дорученої йому основної роботи, доцільно також визначити здібності робітника до праці у межах "вільного" проміжку часу, що залишається у робітника в такті потоку. Для їх розрахунку пропонуються такі формули: 


$$
K_{\text {здб.роб.(вільн.иром.час) }}=I_{\text {здб. }} \cdot\left(t-\sum_{j=1}^{m} N_{\text {факт.(осн. })_{j}}\right),
$$

де $\sum_{j=1}^{m} N_{\text {факт.(осн.) }}$ - витрати часу $j$-го робітника у такті потоку на виконання основної роботи, с.

або

$$
K_{\text {здб.роб.(вільн.иром.час) }}=I_{\text {здб. }} \cdot t-\sum_{i=1}^{n} N_{\text {норм.(осн. })_{i}} \cdot
$$

де $N_{\text {норм.(осн. })_{i}}-$ необхідні витрати часу $i$-го робітника середніх здібностей до праці на виконання основної роботи, с.

В цьому випадку здібності робітника до праці за такт потоку можна визначити також за наступною формулою:

$$
K_{\text {зоб.роб.(такт.) }}=\sum_{i=1}^{n} N_{\text {норм.(осн.) })_{i}}+K_{\text {здб.роб.(вільн.пром.час) }} .
$$

Узагальнюючи науково-методичні підходи щодо визначення здібностей робітника до праці на прикладі потоково-конвеєрного виробництва та розглядаючи вирішення цієї проблеми з позиції індукції, пропонується така загальна формула для їх визначення:

$$
K_{\text {зоб.роб. }}=I_{\text {здб. }} \cdot \Psi
$$

де $Ч$ - період часу, за який встановлюються здібності робітника до праці (такт потоку, година, зміна, доба, тиждень, місяць, рік і т. ін.).

Виходячи з цієї загальної формули, визначення здібностей робітників до праці за конкретні наступні розрахункові періоди часу пропонується робити таким чином:

1. Кількісна оцінка здібностей робітника до праці за годину:

$$
K_{\text {здб.роб.(год.) }}=I_{\text {здб. }} \cdot \Gamma,
$$

де $\Gamma$ - година часу, год.

2. Кількісна оцінка здібностей робітника до праці за зміну:

$$
K_{\text {здб.роб.(зм.) }}=I_{\text {здб. }} \cdot \Gamma \cdot T_{\text {зм. }},
$$

де $T_{\text {зм. }}$ - тривалість зміни, год.

3. Кількісна оцінка здібностей робітника до праці за тиждень: 


$$
K_{\text {здб.роб.(тжљ.) }}=I_{\text {здб. }} \cdot \Gamma \cdot T_{\text {зм. }} \cdot S,
$$

де $S$ - кількість робочих днів у тижні, днів.

4. Кількісна оцінка здібностей робітника до праці за місяць:

$$
K_{\text {здб.роб.(міс.) }}=I_{\text {здб. }} \cdot \Gamma \cdot T_{\text {зм. }} \cdot h,
$$

де $h$ - кількість робочих днів у місяці, днів.

5. Кількісна оцінка здібностей робітника до праці за рік:

$$
K_{\text {зоб.роб.(рік.) }}=I_{\text {здб. }} \cdot \Gamma \cdot T_{\text {зм. }} \cdot h \cdot R,
$$

де $R$ - кількість робочих місяців за рік.

У тому разі, якщо в якості міри праці у виробництві, з огляду на притаманні йому специфічні особливості, застосовується норма виробітку продукції, то індекс здібностей робітника до праці пропонується визначати за наступною формулою:

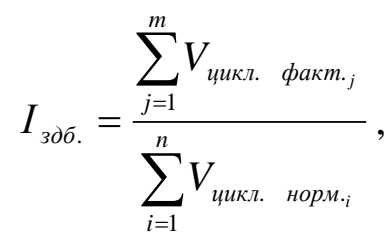

де $V_{\text {цикл. норм.і }}$ - кількість одиниць роботи (кількість виробів, деталей і т. ін.), яка повинна бути виконана або виготовлена $j$-им робітником середніх здібностей до праці в циклі операції за такт потоку в певних організаційно-технічних умовах виробництва, натур. од.;

$V_{\text {иикл. факт. }}-$ кількість одиниць роботи (кількість виробів, деталей і т. ін.), яку може виконати або виготовити $i$-ий конкретний робітник (згідно зі своїми здібностями до праці) в циклі операції за такт потоку в тих самих організаційно-технічних умовах виробництва, натур. од.

Кількісна оцінка здібностей робітника до праці у цьому випадку визначиться за такою формулою:

$$
K_{\text {здб.роб. }}=I_{\text {здб. }} \cdot \frac{F}{\sum_{i=1}^{n} N_{\text {нор.м }}},
$$

де $F$ - ефективний фонд робочого часу, за який встановлюються здібності робітника до праці (секунд, хвилин, годин і т. ін.);

$N_{\text {нори. }}-$ необхідні витрати часу $i$-го робітника на виконання роботи або комплексу робіт в циклі операції в певних організаційно-технічних умовах виробництва у відповідних одиницях виміру.

Кількісна оцінка здібностей робітників до праці показує обсяг нормативного трудового навантаження, який може за визначений час виконати певний робітник у 
даних організаційно-технічних умовах виробництва та обміняти на відповідний розмір заробітної плати. Це дозволяє забезпечити передумови, по-перше, щодо найбільш повного та ефективного використання робочої сили кожного робітника, що $\epsilon$ основою високопродуктивної праці та успішного вирішення на цій основі різноманітних виробничих, соціальних, економічних та інших завдань підприємства, а по-друге, щодо створення найбільш ефективного механізму регулювання оплати праці робітників, що зумовлює їх прагнення до найбільш повного використання своєї робочої сили та досягнення найвищих результатів праці.

Разом із тим, у реальних організаційно-технічних умовах виробництва в результаті дії різних організаційних, технічних, економічних, екологічних, санітарних та інших факторів робітнику не завжди може бути встановлений саме той обсяг нормативного трудового навантаження, який відповідає його здібностям до праці. Ця обставина потребує визначення реального трудового навантаження, що може фактично виконати певний робітник в певних умовах виробництва. Робити це пропонується наступним чином.

Насамперед треба виходячи, з одного боку, зі встановлених здібностей робітника до праці та його особистих потреб у праці, а з іншого - з реальних умов і можливостей виробництва, визначити для виконання робітнику певну роботу. Різновиди цих робіт повинні визначатися в кожному окремому випадку, виходячи 3 особливостей технологічного процесу, організації праці і виробництва та носити доцільний характер. Потім необхідно провести всебічне дослідження цієї роботи із визначенням як необхідних витрат часу, які потребуються для їі виконання у даних умовах виробництва 3 витратами часу, які фактично витрачає конкретний робітник на іiі виконання в тих самих умовах виробництва. Їх порівняння дозволить визначити саме той обсяг нормативного трудового навантаження, що реально може виконувати робітник.

Що стосується потоково-конвеєрного виробництва, то враховуючи специфіку його функціонування, тут пропонується дотримуватись наступних вимог. Необхідні витрати часу на виконання додаткової роботи не повинні перевищувати кількісної оцінки здібностей робітника до праці, що встановлені йому в межах “вільного” проміжку часу. А витрати праці робітника - проміжку “вільного” часу, що залишається у нього після виконання основної роботи. У цілому витрати часу робітника на виконання основної та додаткової роботи не повинні перевищувати такту потоку. Вихід за ці межі буде свідчити, що робітник не справляється 3 дорученим обсягом нормативного трудового навантаження і воно повинно бути йому негайно зменшено. У протилежному випадку неминуче порушення ритму конвеєра та збій його роботи. У цьому разі повинний бути зроблений перерозподіл роботи і робітнику підібрана інша робота.

Висновки. Формування в Україні ринкової економіки вимагає визначення розміру оплати праці робітників на основі її купівлі-продажу між найманим робітником та власником-роботодавцем. Ці обставини вимагають визначення здібностей робітників до праці, які зумовлюють обсяг особистого нормативного трудового навантаження, що може виконати певний робітник за визначений проміжок часу в певних умовах виробництва та подати його на продаж на відповідний розмір заробітної плати. Наукове і практичне вирішення цієї проблеми вимагає розробки відповідного наукового методу. Найбільш ймовірна перспектива створення такого методу лежить через пошук інтеграції різноманітних способів встановлення індивідуальних та необхідних витрат праці та сучасних аналітичних методів нормування праці шляхом їх доповнення та взаємозбагачення. 
Індивідуальні витрати праці показують, скільки потрібно часу конкретному робітнику на виконання деякої операції (роботи або комплексу робіт) у певних умовах виробництва. Нормативні витрати часу показують скільки потрібно необхідних витрат часу на виконання цієї ж самої операції та в тих самих умовах виробництва. Співвідношення індивідуальних витрат часу з необхідними дозволяє визначити здатність конкретного робітника виконати певний обсяг нормативного трудового навантаження за визначений проміжок часу в певних умовах виробництва. Отже, вимір здібностей робітника до праці припускає, по-перше, дослідження організаційно-технічних умов виробництва та визначення найбільш оптимальної технології трудового процесу виконання операції в цих умовах, по-друге, визначення необхідних витрат праці, що потрібні робітнику середніх здібностей до праці для виконання операції у визначених умовах виробництва, по-третє, встановлення індивідуальних витрат праці конкретного робітника на виконання цієї ж операції в тих самих умовах виробництва, виконуючи, таким чином, роль сполучної ланки між функціонально-трудовим аналізом, встановленням необхідних витрат праці та визначенням індивідуальних витрат праці конкретного робітника.

3 вищезазначеного випливає, що вимір здібностей робітника до праці за своєю суттю $є$ водночас функціонально-технологічне та соціально-економічне завдання. 3 одного боку, необхідно створити відповідний науковий метод, що забезпечує необхідну якість та точність виміру здібностей робітника до праці, а з іншого - забезпечити основу визначення розміру оплати праці та формування нового високоефективного механізму їі регулювання.

\section{СПИСОК ВИКОРИСТАНИХ ДЖЕРЕЛ}

1. Брагинский С.В., Певзнер Я.А. Политическая экономия: дискуссионные проблемы, пути обновления. - М.: Мысль, 1991. - 299 с.

2. Крутецкий В. А. Проблемы формирования и развития способностей // Вопросы психологии. - 1972. - №2. - С. 3-14.

3. Леонтьев В. Экономические эссе. Теории, исследования, факты и политика: Пер. с англ. - М.: Политиздат, 1990. - 415 с.

4. Людвиг фон Мизес. Человеческая деятельность. Трактат по экономической теории / Пер. 3-го испр. англ. изд. А.В. Куряева. - М.: Экономика, 2000. - 878 с.

5. Економічна теорія: Політекономія: Підручник / За ред. В.М. Тарасевича. - К.: Знання, 2012. $-206 \mathrm{c}$. 